\title{
Road to Alzheimer's Disease: The Pathomechanism Underlying
}

\author{
R. Anand Alka Kaushal Willayat Yousuf Wani Kiran Dip Gill \\ Department of Biochemistry, Postgraduate Institute of Medical Education and Research, Chandigarh, India
}

\section{Key Words}

Alzheimer's disease $\cdot$ Amyloid $\cdot$ Dementia $\cdot$ Neurofibrillary tangles $\cdot$ Oxidative stress $\cdot$ Senile plaques $\cdot$ Tau protein

\begin{abstract}
Alzheimer's disease (AD), the most common cause of dementia, results from the interplay of various deregulated mechanisms triggering a complex pathophysiology. The neurons suffer from and slowly succumb to multiple irreversible damages, resulting in cell death and thus memory deficits that characterize AD. In spite of our vast knowledge, it is still unclear as to when the disease process starts and how long the perturbations continue before the disease manifests. Recent studies provide sufficient evidence to prove amyloid $\beta(A \beta)$ as the primary cause initiating secondary events, but $A \beta$ is also known to be produced under normal conditions and to possess physiological roles, hence, the questions that remain are: What are the factors that lead to abnormal $A \beta$ production? When does $A \beta$ turn into a pathological molecule? What is the chain of events that follows $A \beta$ ? The answers are still under debate, and further insight may help us in creating better diagnostic and therapeutic options in AD. The present article attempts to review the current literature regarding $A D$ pathophysiology and proposes a pathophysiologic cascade in AD.
\end{abstract}

Copyright @ 2011 S. Karger AG, Basel
(ㄷ) 2011 S. Karger AG, Basel 1015-2008/12/0792-0055\$38.00/0

Fax +41613061234 E-Mail karger@karger.ch www.karger.com

\section{Introduction}

Alzheimer's disease (AD), a neurodegenerative disorder characterized by slowly progressive dementia and brain atrophy, is peculiar with respect to its subtle onset, insidious course, lack of simple diagnostic tests, effective treatment and last but not least its poor prognosis. AD is the most common type of dementia, accounting for $60-$ $80 \%$ of cases [1]. Every 71 s someone in America develops $\mathrm{AD}$; by 2050, it is expected to occur every $33 \mathrm{~s}$ [1], and globally there is a new case every $7 \mathrm{~s}[2]$. AD poses an emotional and economic burden to the patient's family as well as society due to the necessity of caregiving and loss of wages. The etiology of $\mathrm{AD}$ is multifactorial, involving a host of genetic, environmental and behavioral components. The greatest risk factor is advancing age. The incidence is $1 \%$ for those aged $\leq 60$ years and roughly doubles every 5 years thereafter [3]. Other risk factors that may be associated with the development of $\mathrm{AD}$ include a positive family history, severe head trauma, female gender, previous depression and vascular factors [4]. The disease is divided into two subtypes depending on the age at onset: early-onset AD (EOAD) and late-onset AD (LOAD). EOAD accounts for approximately $1-6 \%$ of all cases and manifests roughly between 30 and 60 or 65 years. LOAD, the most common form of $\mathrm{AD}$, accounting for around

Tel. +91 1722755 177, E-Mail kdgill2002@yahoo.co.in 


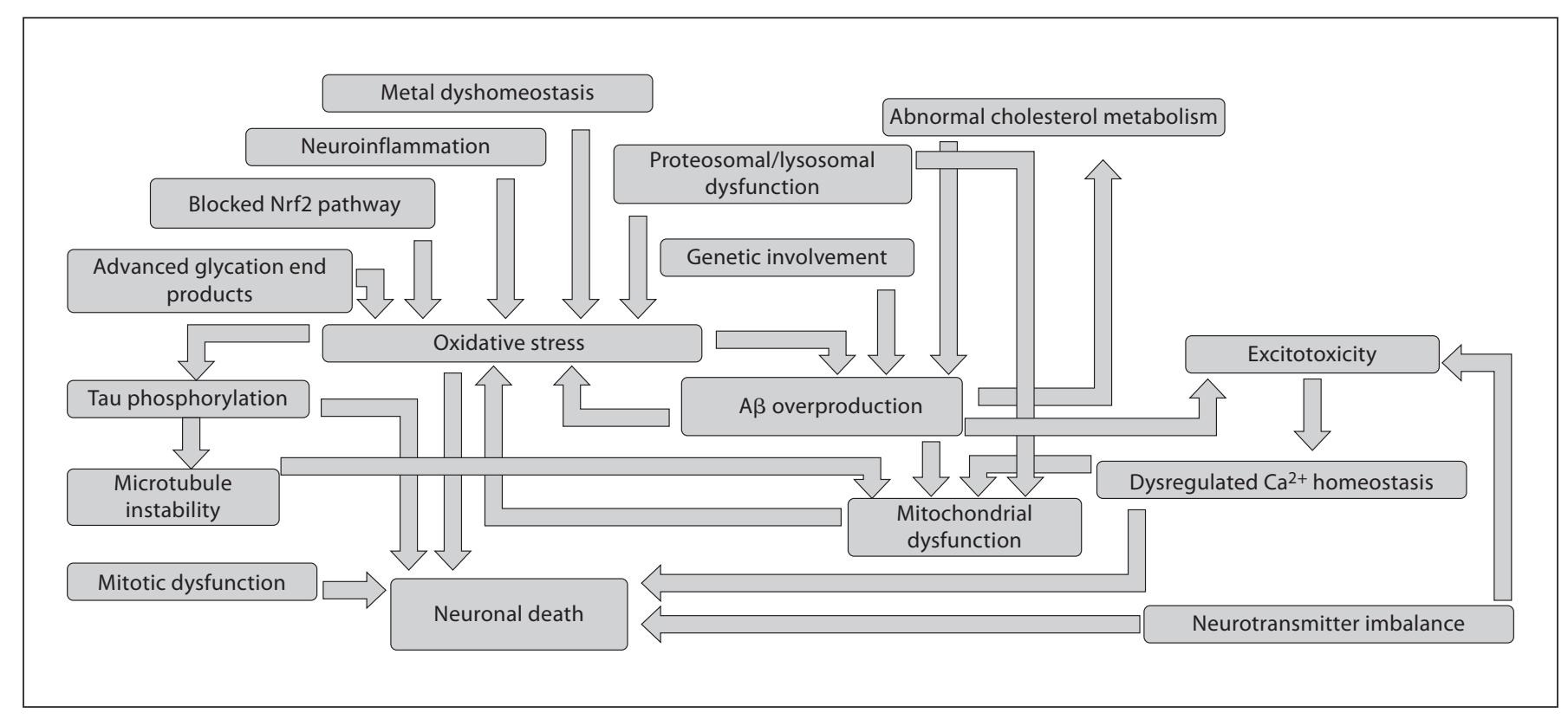

Fig. 1. Overview of pathophysiologic mechanisms in AD.

$90 \%$ of cases, is defined as $\mathrm{AD}$ with an age at onset later than 60 or 65 years. Both EOAD and LOAD may occur in people with a positive family history of $\mathrm{AD}$ [5]. The clinical phases of AD have been divided into the latent/ asymptomatic phase, during which the disease process has started but symptoms do not yet manifest, the prodromal phase/mild cognitive impairment (MCI) and the phase of dementia [6].

\section{Pathophysiology of AD}

AD seems to result from a variety of dysregulated mechanisms which incur slowly accumulating damage to the neurons, finally pronouncing their death. The diverse mechanisms hence pose a great difficulty in gaining control over the disease. Various reviews comprehensively discuss the individual mechanisms involved in AD [518], but a summarized and integrated pathomechanism has not been described to date and the present review is focused on accomplishing this task.

Our understanding of the pathophysiology of $\mathrm{AD}$ is constantly changing. For instance the tangles, a wellknown pathological hallmark of $\mathrm{AD}$, earlier thought to be responsible for the disease, now rather seem to reflect the injury which the neurons have endured over a long time. The notion that amyloid $\beta$ peptide $(A \beta)$ and phos- phorylated tau (P-tau) are pathologic molecules is slowly changing, and their physiological roles as a cellular adaptive strategy to oxidative stress (OXS) are just being realized. Recent evidence indicates that $A \beta$ molecules are produced as cellular defense reaction to OXS and various deranged mechanisms, such as persistent OXS, mitochondrial dysfunction, $A \beta$ production, neurofibrillary tangle (NFT) accumulation, hormone imbalance, inflammation, mitotic dysfunction, impaired calcium homeostasis and genetic components, play a role in the disease process. Though the mechanisms are diverse, neuronal death, the inevitable event, ensues resulting in $\mathrm{AD}$. An overview of the various mechanisms involved and their interaction is shown in figure 1.

OXS - 'Origin Myth of $A D$ '

Despite all of the evidence that links AD to etiologic components, details on the mechanism which triggers the pathological cascade still remain to be established. The 'two hit hypothesis' [9] and the 'LEARn' model [19] provide the most comprehensive explanation for the beginning of the cellular insult in AD. OXS, in particular chronic, mild and tolerable levels of OXS, seems to be the major factor initiating AD [9]. Various mechanisms have been reported to cause OXS in AD (table 1).

Abnormal metal homeostasis in the vicinity of neurons is a reason for OXS [7]. Various metals are implicat- 
ed in the pathogenesis of $\mathrm{AD}$, including iron, copper and zinc [20]. Iron accumulation was noted in the hippocampus, cerebral cortex, basal nucleus of Meynert and also in AD lesions - senile plaques and NFT. In addition, iron, a transition metal, can form $\mathrm{OH}^{*}$ via the Fenton reaction [21]. Impaired homeostasis of copper, another important metal component of cytochrome, is also implicated in OXS in AD. Copper has been shown to play a role in reactive oxygen species (ROS) production through its binding to $A \beta$ protein precursor (A $\beta P P)$. Copper is also highly concentrated within $A \beta$ plaques, creating conditions for Fenton-type reactions through the reduction of $\mathrm{Cu}(\mathrm{II})$ by $\mathrm{A} \beta-\mathrm{H}_{2} \mathrm{O}_{2}$ [7]. Aluminum has also received attention in $\mathrm{AD}$ [22]; although not convincingly demonstrated, aluminum is highly concentrated in plaques and NFT lesions, suggesting its involvement in AD pathogenesis. Unlike transition metal ions, aluminum cannot initiate redox reactions; however, evidence indicates that it can act synergistically with iron to increase free radical damage [23].

Advanced glycation end products (AGEs) are another source of OXS. In the presence of transition metals, AGEs can either undergo redox cycling [24] or they interact with specific receptors such as the receptor for AGEs (RAGE) [25] and the class A scavenger receptor [26] resulting in ROS production. The proteosomal dysfunction which ensues with advancing age [27] and the lysosomes which accumulate lipofuscin [28] lose their degradative capacity, thus accumulating dysfunctional organelles and contributing to OXS. The hormone dyshomeostasis which ensues with advancing age also contributes to oxidative stress. Studies have shown that estrogen, testosterone and to a lesser extent progesterone have antioxidant, -inflammatory and -amyloid properties, and luteinizing hormone (LH) has opposite effects [29]. With advancing age, the levels of estrogen and testosterone fall, and LH rises, tilting the balance towards a prooxidant state and resulting in OXS. The activated microglia/astrocytes which surround the plaques also have the potential to produce large amounts of ROS by various mechanisms $[30,31]$.

Though evidence suggests that $A \beta$ fibers are produced as a compensatory response in virtue of their antioxidant properties [32], $A \beta$, when they aggregate and become aged, are capable of oxidizing various biomolecules. $A \beta$ can induce peroxidation of membrane lipids [33] and lipoproteins [34], generate $\mathrm{H}_{2} \mathrm{O}_{2}$ [35] and hydroxynonenal [36] in neurons, damages deoxyribonucleic acid (DNA) [37] and inactivate transport enzymes [38]. A $\beta$ can also lead to OXS indirectly by causing mitochondrial dys-
Table 1. Cause of OXS in AD

Metal dyshomeostasis

AGE

Hormone imbalance

Microglial/astrocyte activation

A $\beta$ fibers

Proteosomal/lysosomal dysfunction

Mitochondrial dysfunction

function. The binding of $A \beta\left(A \beta_{40}\right.$ and $\left.A \beta_{42}\right)$ with heme, forming the $A \beta$-heme complex, has recently been demonstrated [39]. Thus $A \beta$ possibly binds to the newly synthesized heme pool, called the 'regulatory heme' reducing its cellular availability for the synthesis of electron transport chain components [40]. There is also a coexistent defect in several key enzymes of oxidative metabolism, including $\alpha$-ketoglutarate dehydrogenase and pyruvate dehydrogenase complexes, and cytochrome oxidase in AD [41-43]. The defects in the enzyme complexes could result from the mutations that the mitochondrial DNA sustains as a result of OXS [44, 45].

Studies indicate a decrease in the number of mitochondria per neuron, increased dysmorphic mitochondria and abnormal turnover of mitochondrial components [46]. The decrease in the mitochondrial number and morphological changes occur due to abnormal mitochondrial dynamics. Expression of proteins involved in mitochondrial fusion is significantly reduced, while levels of proteins involved in mitochondrial fission are increased in the hippocampal tissue of $\mathrm{AD}$ patients, thus confirming an imbalance between mitochondrial fission and fusion in pyramidal neurons in $\mathrm{AD}$ [47]. The ensuing mitochondrial dysfunction not only leads to ROS production but also to a chronic energy crisis in the neurons. The energy depletion may also increase the catabolism of membrane cholesterol [48], and when the reduction in cholesterol is moderate, there is a disorganization of lipid rafts that favors the contact between $\beta$-secretase and amyloid precursor protein (APP), which results in increased $\mathrm{A} \beta$ production [49].

Thus, OXS, irrespective of its cause in neurons in $\mathrm{AD}$, is sustained, resulting in chronic and persistent OXS. The uniqueness of OXS in AD is that it does not overwhelm oxidative defenses and few neurons $(<1 / 10,000$ at any given time) exhibit signs of apoptosis [50], as would be expected under conditions of acute and high-level OXS. Therefore, chronic, tolerable OXS occurs and neurons resort to adaptive responses [51] rather than cell death. 


\section{Impaired Antioxidant Defense}

Cells normally respond to OXS through an endogenous mechanism regulated at the transcriptional level. A common promoter element, called the antioxidant response element, regulates the genes whose products participate in reducing OXS. Its promoter is bound by a transcription factor, nuclear factor $\mathrm{E}_{2}$-related factor 2 (Nrf2), which activates transcription in response to OXS [52]. Under basal conditions, interaction with Keap1 (kelchlike $\mathrm{ECH}$-associated protein 1) sequesters $\mathrm{Nrf2}$ in the $\mathrm{cy}$ toplasm [53]. Either oxidation of sulfhydryl groups on specific cysteines in Keap1 [54] or phosphorylation of Keap1 and/or Nrf2 induces Keap1 to release Nrf2 [55]. Keap1-released Nrf2 gets stabilized, translocates from the cytoplasm to the nucleus and activates the expression of detoxification enzymes, antioxidant enzymes, reducing molecules and Nrf2 itself [56].

The Nrf2 pathway is important because it has been observed that overexpression of $\mathrm{Nrf} 2$ can rescue neurons from mitochondrial complex II inhibition [57] and neurons lacking Nrf2 are more susceptible to OXS through $\mathrm{H}_{2} \mathrm{O}_{2}$ [58]. Given the presence of OXS in $\mathrm{AD}$, we would expect an upregulation of Nrf2 activity in the nuclei of neurons and astrocytes during disease progression; however, the levels of some antioxidant response elementcontaining gene products are reduced, suggesting disruption of this pathway [11]. In AD, Nrf2 predominantly occurs in the cytoplasm in hippocampal neurons and not in the nucleus, reflecting impaired nuclear trafficking, suggesting a process blocking Nrf2 nuclear activity in $\mathrm{AD}$, potentially contributing to neuronal dysfunction and/or loss [11].

\section{OXS Signaling}

Therefore, in a chronic OXS situation when induction of antioxidant enzymes is insufficient, neurons seem to resort to further structural adaptations like $A \beta$ production, tau hyperphosphorylation and neuronal hypertrophy by inducing multiple cell signaling pathways. The phosphorylation cascade is modulated by the sequential and collective action of distinct kinases, all of which appear to be related to $\mathrm{AD}$ pathophysiology. The 3 members of the MAP kinase family: stress-activated protein kinase (SAPK)/c-Jun amino terminal kinase (JNK), p38 kinase and extracellular signal-regulated protein kinases (ERKs) [59] have received attention owing to their overexpression in $\mathrm{AD}[60]$.

The kinases which are known to phosphorylate tau include ERK1 and ERK2 [61], JNK [62], p38 kinase [63], glycogen synthase kinase-3 (GSK3) [64], cyclin-depen- dent kinase-5 (CDK5) [65], casein kinase I (CK1) [66], cAMP-dependent protein kinase A (PKA) [67] and calcium/calmodulin-dependent protein kinase II (CaM kinase II) [68]. Another interesting molecule playing a role in tau phosphorylation is caspase 2 , which cleaves tau at D421 producing $\Delta$ tau. $\Delta$ Tau is now susceptible to phosphorylation by GSK3 and is more prone to NFT formation [69]. Apart from tau phosphorylation, JNK/SAPK have also been seen to increase amyloid production from neurons [70]. Studies from several groups consistently show that $A \beta$ induces a two- to threefold activation of JNK/SAPK in different neuronal cell types [71, 72]. A $\beta$ again may serve to provide a positive feedback to SAPK resulting in their continued activation. It is possible that OXS, as an earlier event, may activate JNK/SAPK; and that elevated levels of $A \beta$, as a later event, contribute to the continued and chronic activation of JNK/SAPK [73]. $\beta$-Site APP-cleaving enzyme (BACE), an aspartyl protease with $\beta$-secretase activity [74], can be induced by OXS [75], which in turn leads to a proportional elevation in the carboxyl-terminal fragments (CTFs) of APP. Since A $\beta$ is also a source of ROS, OXS production and $A \beta$ generation may set up a vicious cycle, in which OXS contributes to $A \beta$ accumulation, and $A \beta$ in turn induces OXS, thus further enhancing $A \beta$ production [73].

\section{Hormones and Amyloidogenesis}

The association between hormone imbalance and OXS was already briefly mentioned. A large body of evidence indicates that estrogen, progesterone and testosterone are neuroprotective, and, consistent with it, an association between $\mathrm{AD}$ and depleted levels of estrogen in women, and testosterone in men, has been reported [76, 77]. Apart from the antioxidant effect, estrogen, testosterone and progesterone to some extent possess (i) antiinflammatory actions, regulating a wide range of microglial functions, including expression of cytokines, cell surface molecules, apoptotic signaling pathways and free radical generation [78], and (ii) antiamyloidogenic properties, resulting in an increase in the secretion of $\alpha$-APPs and a decrease in $A \beta$ production in cultured human neuroblastoma and cerebrocortical neurons [79]. A recent study has also revealed a potential correlation between apolipoproteins $\mathrm{E}$ (ApoE) genotypes and testosterone levels, with low testosterone levels and ApoE $\varepsilon 4$ being positively associated with small hippocampal volumes [80].

It has also been shown that in $\mathrm{AD}$ patients, serum concentrations of $\mathrm{LH}$ are approximately twice as high as in age-matched controls [81], and elevated LH is observed in the $\mathrm{AD}$-vulnerable hippocampus [82]. Unlike estrogen 
Table 2. Genes involved and the contribution to $\mathrm{AD}$

\begin{tabular}{|c|c|c|c|}
\hline Gene & Chromosome & Inheritance & Effect \\
\hline APP & $21 \mathrm{q} 21$ & $\begin{array}{l}\text { autosomal } \\
\text { dominant }\end{array}$ & $\begin{array}{l}10-15 \% \text { of } E O A D \text {; alter processing of } A P P \text {, increasing } A \beta_{42} \text {, } \\
\text { decreasing } A \beta_{40} \text { peptide levels }\end{array}$ \\
\hline PSEN1 & $14 \mathrm{q} 24.2$ & $\begin{array}{l}\text { autosomal } \\
\text { dominant }\end{array}$ & $\begin{array}{l}18-80 \% \text { of } E O A D \text { cases; increased } A \beta_{42} \text { production, } \\
\text { decreased } A \beta_{40} \text { production }\end{array}$ \\
\hline PSEN2 & $1 \mathrm{q} 42.13$ & $\begin{array}{l}\text { autosomal } \\
\text { dominant }\end{array}$ & $\begin{array}{l}\text { rare; increase the ratio of } A \beta_{42} \text { to } A \beta_{40} \text {, less effectively than } \\
\text { PSEN1 }\end{array}$ \\
\hline APOE & $19 q 13.32$ & sporadic & $\begin{array}{l}19 \% \text { of familial LOAD; isoform-specific toxicity, ApoE } \varepsilon 4- \\
\text { mediated amyloid aggregation, and ApoE } \varepsilon 4 \text {-mediated tau } \\
\text { hyperphosphorylation increased A } \beta \text { transport into the } \\
\text { brain, defective } A \beta \text { clearance, immunomodulation }\end{array}$ \\
\hline
\end{tabular}

and testosterone, LH is implicated in the promotion of amyloidogenic processing of APP and in the accumulation of $A \beta$ and amyloidogenic APP-CTFs, whilst decreasing secretion of soluble $\alpha$-APPs [83]. LH receptor is found to be expressed on a variety of immune cells throughout the body, including macrophages of the brain [84], thus suggesting a role for $\mathrm{LH}$ in modulating inflammation. LH dose-dependently increases secretion of reactive oxygen and nitrogen species from human blood leukocytes [85] and upregulates 5'-lipoxygenase, an enzyme important in proinflammatory signaling pathways in hippocampal cell cultures [29].

Thus, with progressive aging and reproductive senescence, there is a gradual fall in neuroprotective hormones, estrogen, progesterone and testosterone with rising $\mathrm{LH}$ levels contributing to OXS, inflammation and amyloidogenesis, adding to the pathogenesis of $\mathrm{AD}$.

\section{Role of Genetics in Amyloidogenesis}

The early-onset familial forms of AD have an autosomal dominant inheritance linked to 3 genes: APP and presenilins 1 (PSEN1) and 2 (PSEN2), while the most common sporadic form is consistently associated with only 1 gene, the APOE gene [5]. The genes involved and their role in the contribution to AD pathology is summarized in table 2 . The genetic abnormalities thus introduce $\mathrm{A} \beta$ relatively early into the game initiating the disease pathology resulting in EOAD. This again correlates well with the proposed pathophysiological cascade in LOAD, where OXS is the early abnormality with $A \beta$ entry at a relatively later part, and hence late manifestation of the disease.

Pathomechanism Underlying AD
Amyloid- $\beta$ Peptide and Hyperphosphorylated Tau

Protein - 'Friends That Turn Foes'

Chronic mild OXS produces compensatory adaptive mechanisms in the neuron which are initially temporary but later become permanent changes. Though $A \beta$ fibers are one of the pathological hallmarks of $\mathrm{AD}$, it is now believed that the peptide has several physiological roles [18] and is present in the cerebrospinal fluid (CSF) and plasma of healthy individuals throughout life [86]. It has been shown that neurons respond to OXS, both in vitro and in vivo, by increasing $A \beta$ production. $A \beta$ is believed to possess antioxidant properties [32] and some authors propose that diffuse amyloid plaques may be a compensatory response aimed at reducing OXS, because a negative correlation has been observed between $A \beta$ deposition and oxidative damage in patients with Down's syndrome as well as in $\mathrm{AD}$ [87-89]. $\mathrm{A} \beta$ also strongly chelates zinc, iron and copper [20], suggesting that one function of $A \beta$ is also to sequester these metal ions. The role of $A \beta$ in maintaining neuroplasticity is also appreciated, and APP has been believed to possess a trophic role [90, 91], with increased APP levels during conditions of increased plasticity. Hence, $A \beta$ production by neurons might be a compensatory response to combat OXS as well maintenance of plasticity.

However, it has been seen that $A \beta$ can also turn into a nasty foe creating toxicity. The condition under which $\mathrm{A} \beta$ ceases to act as an antioxidant and functions as a prooxidant are not clearly understood, but may be dependent on the concentration of the peptide. With time, $A \beta$ production exceeds the capacity for its clearance, and they begin to accumulate, increasing its concentration towards toxic levels. $A \beta$ has the capability to induce oxida- 
tion of biomolecules provided three important conditions are satisfied: fibrillation, the presence of transition metals and methionine-35. Thus, when conditions turn favorable, the prooxidant effect becomes dominant and $A \beta$ turns detrimental. There is a dynamic equilibrium between $\mathrm{A} \beta$ fibrils, oligomers and monomers, and oligomeric species are more toxic than monomers or fibrils. Early memory impairment and synaptic dysfunction correlate better with the levels of oligomeric $A \beta$ but not with fibrillar species [92]. With $A \beta$ available in abundance, the oligomeric species may be readily available for ensuing damage.

P-tau is another well-known pathological hallmark of $\mathrm{AD}$, which also seems to be an adaptive modification but which results in untoward effects. Tau is essentially present in neurons and mainly functions to stabilize microtubules by interacting via its microtubule-binding domains. By regulating microtubule assembly, tau has a role in modulating the functional organization of the neuron, particularly in axonal morphology, growth and polarity [93]. The tau protein has multiple phosphorylation sites which get phosphorylated in AD. There is evidence that P-tau exerts protective functions. OXS and modification of tau by products of OXS [94] enable neurons to survive for decades [95]. Neurofilament and tau proteins appear adapted to OXS by virtue of their high content of lysineserine-proline (KSP) domains [96] and may function as a buffer by absorbing lipoxidation- and glycoxidation-derived aldehydes [97]. Phosphorylation also increases the tendency of tau to aggregate readily into paired helical filaments. The microtubule-binding property of tau also seems to be dependent on its state of phosphorylation. Ptau binds with a lesser affinity to microtubules [98], resulting in microtubule instability. In AD, P-tau accumulates in neurons, aggregates into paired helical filaments and loses its microtubule binding and stabilizing function, leading to neuronal degeneration [99].

Thus, both $A \beta$ as well P-tau may be intended for counteracting OXS and maintaining neurogenesis, but following irreversible changes, they impair cellular function and decrease neuronal function.

\section{$A \beta$ and Cholesterol Metabolism}

The role of cholesterol in the pathogenesis of $\mathrm{AD}$ has been given less importance until recently; nonetheless, in neuronal membranes, cholesterol induces large changes in membrane fluidity, regulating the activity of several membrane proteins. A higher input of cholesterol is needed for the formation of new synapses [100], and high-density lipoproteins (HDL) are critical for the maturation of synapses and maintenance of synaptic plasticity [101]. A high level of low-density lipoprotein and elevated total cholesterol levels are associated with cognitive impairment [102], and high levels of HDL cholesterol were associated with protection against AD [103]. The presence of the ApoEc4 allele, a cholesterol carrier, another major genetic risk factor for sporadic $\mathrm{AD}$, also suggests that brain cholesterol homeostasis is involved in AD [104]. Cholesterol and $A \beta$ seem to interact, with one increasing the production of the other and vice versa. Cholesterol is necessary for $A \beta$ production [105], and hypercholesterolemia is associated with increased intraneuronal and extracellular accumulation of $A \beta$ [106]. $A \beta$, on the other hand, modifies cellular cholesterol distribution and the rate of cholesterol esterification altering cholesterol homeostasis [107]. A $\beta$ also increases hippocampal lipid synthesis and cholesterol uptake [108], and promotes the accumulation of cholesterol and ceramides [109].

Apolipoproteins play a role in $\mathrm{A} \beta$ metabolism and transport, although they do not cross the blood-brain barrier (BBB) and may regulate the flux of $A \beta$ between the central nervous system (CNS) and the periphery. ApoE $\varepsilon 4$ is thought to increase translocation of $A \beta$ from blood to brain [110] and results in increased $A \beta$ deposition in the brain. Mouse models that overproduce and deposit $A \beta$ combined with transgenic animals lacking ApoE tend to have reduced $A \beta$ deposition [111], suggesting a role for $A p o E$ in $A \beta$ transport. Apart from its role in $A \beta$ trafficking, ApoE also performs immunomodulatory functions. In the brain, the principal cells secreting ApoE are astrocytes and microglia [112], and ApoE $\varepsilon 4$ is associated with increased production of proinflammatory cytokines compared with ApoEs3 [113]. Even a single amino acid change that differentiates ApoE $\varepsilon 4$ from ApoE $\varepsilon 3$ and ApoE $\varepsilon 2$ in mice results in protein misfolding and endoplasmic reticulum stress in astrocytes, leading to severe cognitive deficits [114]. A $\beta$ and APP also stimulate the formation of the proapoptotic molecule $7 \alpha-$ hydroxycholesterol from cholesterol [115] and neuronal death is again the inevitable result.

\section{Excitotoxicity and $A D$}

Excitotoxicity is another mechanism known to be involved in AD pathophysiology. Excessive stimulation of the N-methyl-D-aspartate (NMDA) receptor and the subsequent massive influx of extracellular $\mathrm{Ca}^{2+}$ can be highly toxic to neurons [12]. A $\beta$ and tau seem to enhance the activation of NMDA receptors [12], resulting in increased $A \beta$ and tau levels. Various studies indicate an imbalance in glutamate homoeostasis with impaired clearing of glu- 
tamate from the synaptic cleft, leading to extracellular glutamate accumulation [116]. Quinolinic acid, the precursor of nicotinamide adenine dinucleotide in the kynurenine pathway, has also been found to be a direct activator of the NMDA receptor contributing to excitotoxicity [13]. The peculiarity with hippocampal neurons in $\mathrm{AD}$ is that, when compared to cholinergic and glutamatergic neurons, the $\gamma$-aminobutyric acid (GABA)ergic neurons are relatively spared, with the precise reason being unknown [117]. Another feature is that chronic growth factor deprivation, which occurs with aging, changes GABA transmission from an inhibitory to an excitatory stimulus, contributing to excitotoxicity [118].

Pathological excitation leads to prolonged, tonic activation, sustained local depolarization and the influx of cations that trigger further glutamate release [119]. This vicious circle could lead primarily to swelling of the neurons because of the increased cation concentration and consequent water influx, and secondly to delayed $\mathrm{Ca}^{2+}$ dependent neuronal degeneration [120].

\section{Perturbed $\mathrm{Ca}^{2+}$ Homeostasis}

Calcium, a vital element for the functioning of neurons, plays multiple physiological roles in the form of controlling membrane excitability, triggering neurotransmitter release, gene expression, neuronal growth, differentiation and transition to apoptosis [121]. Various studies have indicated age-related changes that occur in $\mathrm{Ca}^{2+}$ homeostasis in the form of elevated intracellular $\mathrm{Ca}^{2+}$ levels/enhanced $\mathrm{Ca}^{2+}$ influx through voltage-dependent $\mathrm{Ca}^{2+}$ channels secondary to excitotoxicity; impaired ability of mitochondria to buffer $\mathrm{Ca}^{2+}$, and disturbed $\mathrm{Ca}^{2+}$ regulation in ryanodine and $\mathrm{Ins}(1,4,5) \mathrm{P}_{3}$-sensitive $\mathrm{Ca}^{2+}$ stores [122]. Similar abnormalities in $\mathrm{Ca}^{2+}$ regulation were also observed in neurons exposed to OXS and in patient studies [123]. The various mechanisms due to which $\mathrm{Ca}^{2+}$ metabolism is disturbed have already been reviewed $[10,124]$. Thus $\mathrm{Ca}^{2+}$ metabolism is impaired in sporadic as well as familial AD, implying a vital role in the pathogenesis of $\mathrm{AD}$. The increase in intracellular $\mathrm{Ca}^{2+}$ can thus activate (i) CaM kinase II: producing P-tau; (ii) calpain: producing an active $\mathrm{p} 25 / \mathrm{CDK} 5$ contributing to P-tau; calpain I activation also brings about cytoskeletal breakdown [125]; (iii) calcineurin and calpains: enabling long-term depression and leading to the inhibition of long-term potentiation, modifications in the neuronal cytoskeleton, synaptic loss and neuritic atrophy, and (iv) excessive $\mathrm{Ca}^{2+}$, taken up by mitochondria through mitochondrial $\mathrm{Ca}^{2+}$ uniporter, opening mitochondrial permeability transition pores and leading to apoptosis [124].

\section{Autophagy and $A D$}

Autophagy is a double-edged sword playing protective as well as pathological roles. Insufficient protective autophagy could cause damaged cellular components to accumulate over many years affecting normal cell function. Alternatively, cell death could be the result of overactive, pathological autophagy [126]. The role of autophagy was indicated in studies with mice lacking Atg5 [127] or Atg7 [128] who showed severe neurodegeneration. In neurons, along with the steps involved in formation, autophagosomes and endosomes from the distal axon must be retrogradely transported to the soma in order to fuse with lysosomes [129], so disturbances in any of the steps may deregulate autophagy leading to unwanted consequences. The tau phosphorylation could result in impaired axonal transport of autophagosomes with accumulation in the distal axon. Autophagosomes and other prelysosomal autophagic vacuoles have been noted in AD brains particularly within neuritic processes [130], suggesting impaired axonal transport.

Deregulation can also occur with the intrinsic mechanism for autophagy. Most of the recent evidence points towards proteolytic failure as the major dysregulated step in autophagy [131]. In $\mathrm{AD}$, autophagy may help to protect the cell in the initial stages degrading the dysfunctional mitochondria and the oxidatively damaged components. Damaged mitochondria are subjected to cellular digestion by mitophagy, a specialized kind of protective autophagy. According to the mitochondrial-lysosomal axis theory of aging [132], lysosomes slowly lose their inherent ability to completely remove oxidatively damaged structures [133] and mitochondrial turnover progressively declines with age, resulting in accumulation of damaged organelles, decreased ATP production, release of apoptotic factors and, eventually, cell death. Even internalized $A \beta_{1-42}$ is slowly degraded and therefore accumulates in lysosomes, followed by leakage of lysosomal enzymes into the cytosol and cellular toxicity [134]. In advanced disease, it is possible that the activation of pathological autophagy might also contribute to neuronal death.

Hence, impaired autophagy due to blocked transport of autophagosomes in axons, proteolytic failure in protective autophagy and activation of pathologic autophagy could be involved in the $\mathrm{AD}$ pathophysiology.

\section{Mitotic Dysfunction}

Neurons of the brain have long been considered to reside in a terminally differentiated $\mathrm{G}_{0}$ state, but around 14 years ago, susceptible cortical neurons were shown to display an ectopic presence of various cyclins, cyclin-depen- 
dent kinases and cyclin-dependent kinase inhibitors in $\mathrm{AD}$, indicating the possibility of cell cycle activation $[135$, 136]. Thus susceptible, postmitotic, neuronal populations actually exit $G_{0}$ and reenter the $G_{1}$ phase. This reentry is probably supported by activation of selective signal transduction pathways, transcriptional activation that results in cytoskeletal changes such as tau phosphorylation, alterations in mitochondrial activity and DNA replication [137-139]. Although they may enter the cell cycle they do not progress further, resulting in cell cycle arrest and death. The significance of such a reentrant phenotype is not clear, but a dysregulated cell cycle in these neurons may contribute to their eventual death in $\mathrm{AD}[9]$.

\section{Mechanisms of Neuronal Death}

Though the perturbed mechanisms are diverse in $\mathrm{AD}$, they all lead to the ultimate event, neuronal death. The detection of cleaved caspases and the accumulation of cleaved caspase substrates in post-mortem AD brain tissue have suggested that apoptosis may play a role in the subsequent neuronal loss in AD [140]. Multiple caspases have been implicated in the progression of AD. mRNA expression of caspases 1-3 and 5-9 were elevated in the brain of AD patients compared with controls [141]. Also, the cytoplasmic tail of APP can be cleaved by caspases at $\operatorname{Asp}_{664}\left(\mathrm{APP}_{695}\right)$, generating a new CTF of 31 residues named C31 [142], and the expression of C31 alone is cytotoxic to the cell, thus potentiating the susceptibility to apoptosis. Caspases also cleave tau and enhance NFT formation [69] contributing to synaptic dysfunction and neuronal death. In vitro studies have shown that $A \beta$ induces upregulation of proapoptotic molecules, such as Bax and Bim, and downregulates anti-apoptotic proteins, such as $\mathrm{Bcl}-2, \mathrm{Bcl}-\mathrm{X}_{\mathrm{L}}$ or $\mathrm{Bcl}-\mathrm{w}$, thus again contributing to apoptosis $[143,144]$. As discussed earlier, excessive $\mathrm{Ca}^{2+}$ when taken up by mitochondria through mitochondrial $\mathrm{Ca}^{2+}$ uniporter leads to opening of mitochondrial permeability transition pores and apoptosis [124]. A $\beta$ and APP also can stimulate the formation of $7 \alpha$-hydroxycholesterol, a proapoptotic molecule, from cholesterol [115].

\section{Accounting for $A \beta$ Overproduction}

Although much has been said and done, we are, however, still unable to explain why a person should develop $\mathrm{AD}$ sporadically. We are aware of the key role played by
$A \beta$ in the disease process and in the process of understanding its physiological role, but there are still missing links which need addressing. Comparing the different types of $\mathrm{AD}$, it would not be a surprise that the disease mechanisms may be similar once $A \beta$ assumes the lead role, and what would vary are the different circumstances that result in $A \beta$ accumulation.

$A \beta$ is produced through the proteolysis of APP, a large type 1 transmembrane protein, and initial cleavage of APP by $\beta$-secretase followed by $\gamma$-secretase [145] is essential to release $A \beta$ peptides. BACE1, the authentic $\beta$-secretase in the brain, enables site-specific cleavage precisely at Asp +1 and $\mathrm{Glu}+11$ of $A \beta$ [146], generating the $\mathrm{N}$ terminus of $A \beta$ and a membrane-bound C-terminal fragment called C99. $\gamma$-Secretase processing of C99 produces several mature $A \beta$ peptides with heterogeneous $C$ termini ranging from 38 to 43 residues in length [146]. The two main toxic species are $A \beta_{40}$ and $A \beta_{42}$, with $A \beta_{42}$ assuming only $10 \%$ of $A \beta$ production but more prone to aggregates due to its hydrophobicity [147]. Although the activity of both $\beta$ - and $\gamma$-secretases is needed, BACE activity is thought to be the rate-limiting factor for $A \beta$ production [148], and hence continuous BACE1 activity is essential for sustaining $A \beta$ levels in $A D$.

With EOAD, the mechanism is quite straightforward since it is either due to mutations in APP or presenilin, rendering APP to be processed more towards the $A \beta$ pathway; however, in case of LOAD, the precise reason for $A \beta$ production still remains unclear. Having said that $\mathrm{BACE}$ activity is the rate-limiting factor for $\mathrm{A} \beta$ production, logically, in case of sporadic $\mathrm{AD}$, either there is an increase in BACE activity or levels, or a combination of both; alternatively there could be defective clearance of $\mathrm{A} \beta$. Evidence indicating that familial AD caused by the APP Swedish mutation that only enhances APP cleavage by BACE1 implies elevated BACE1 activity alone can lead to AD. Various studies have shown that levels of BACE1 protein and activity are increased in AD brain [149-151]. BACE is an acute-phase protein, and studies have shown increased enzyme levels in conditions such as OXS [75], hypoxia [152], ischemia [153], traumatic brain injury [154] and impaired glucose metabolism [155]. The abovesaid conditions, being well-known risk factors associated with $\mathrm{AD}$, can result in sustained and up to twofold increased BACE activity [149].

Multiple endogenous pathways exist for $A \beta$ degradation [156] and include neprilysin, insulin-degrading enzyme, endothelin-converting enzyme, angiotensin-converting enzyme and metalloproteinase 9 [156], but their levels are reduced in AD [157]. Apart from the increased 
enzyme activity, defects in $A \beta$ clearance also play an important part in $\mathrm{AD}$ pathogenesis. $\mathrm{A} \beta$ is transported across the BBB in both the blood-to-brain and brain-toblood directions by RAGE [158] and a low-density lipoprotein receptor-related protein (LRP-1) [159], respectively. RAGE expression increases with age at the BBB [160], resulting in more influx, suggesting another mechanism for $A \beta$ accumulation in the CNS. The expression of LRP-1, the transporter responsible for $A \beta$ efflux, is also decreased [161], thus blocking $A \beta$ clearance from the CNS. ApoE $\varepsilon 4$, when present, also contributes to the transfer of $A \beta$ from blood to CNS [110].

However, it is not clear as to which mechanism is impaired early in each case or how many mechanisms are perturbed in $\mathrm{AD}$, and the precise reason for $\mathrm{A} \beta$ accumulation is yet to be defined. The mechanisms resulting in $\mathrm{A} \beta$ accumulation are summarized in table 3 .

\section{Pathoanatomy in AD}

Apart from the peculiarity of the disease process, anatomical involvement as well as progression are also strikingly similar in most cases. It has been well known for a long time that temporoparietal regions are the most affected in AD. Many studies have definitively demonstrated that NFT distribution is initially limited to entorhinal cortices, spreading to temporoparietal association cortices later, followed by frontal and, ultimately, primary sensory and visual areas $[162,163]$. In a study by Thompson et al. [164], the sequence of gray mater involvement in $\mathrm{AD}$ was mapped, and, along with the disparity in cortical involvement, there was asymmetric hemispherical involvement. The left hemisphere is involved first, followed by the right in a similar sequence but after a time lag. Disease progression is also not continuous, and specific regions are relatively spared, for instance primary sensory and motor cortices, until later in disease. Surprisingly, healthy controls also lose gray matter volume at rate of $1 \%$ per year [164], but the loss is limited to the frontal cortex, CA1 and subicular regions of the hippocampus. The loss in gray matter is secondary to cell shrinkage and reduced dendritic length in healthy controls [165] whereas in AD, a combination of these processes as well as substantial neuronal loss is noted [166].

Astonishingly, again there appears to be a reason behind the site-specific involvement in AD. The fact that hippocampi and limbic cortices bear the brunt of injury is not surprising due to their high baseline plasticity and active involvement in memory formation. Increasing ev-
Table 3. Causes of $A \beta$ accumulation in $\mathrm{AD}$

Increased $\beta$-secretase expression and activity

Decrease in $A \beta$-degrading enzymes

Increased RAGE expression/A $\beta$ influx into the $\mathrm{CNS}$

Decreased LRP-1 expression/A $\beta$ efflux

idence highlights the fact that axonal sprouting, dendritic remodeling and perhaps reactive synaptogenesis are higher in the limbic system than in other parts of the cerebral cortex [167, 168]. Further, the markers of axonal sprouting [169], neurotrophic factor expression [170] and dynamics in dendritic growth [171] have been found to be highest in the transentorhinal, entorhinal and hippocampal regions, gradually decreasing in the posterior parietal and prefrontal areas, being almost negligible in the primary motor and sensory areas. This pattern accurately mirrors the sequence and pattern of mapped anatomic loss in AD, which was discussed earlier [164].

The high dynamicity of the neurons in these regions, which demands active metabolism, exposes these neurons to OXS at an early stage, probably explaining their vulnerability in $\mathrm{AD}$. The risk factors of $\mathrm{AD}$, viz aging, the ApoE $\varepsilon 4$ allele [172] and hormone imbalance with reproductive senescence [173], are all known to cause neuronal dysfunction and negatively affect plasticity. To begin with, slowly increasing OXS, secondary to metal accumulation, AGEs or inflammation, might cause subnormal neuronal function, resulting in additional work burden on the neurons to maintain hippocampal function. The neurons now adopt a compensated state in which organ function remains uncompromised, but neurons become now more susceptible to additional blows. Over the years, such compensatory processes would lead to chronically high and eventually unsustainable levels of plasticity-related cellular activity. Recalling the neurotrophic properties of APP [91], the role of P-tau in regulating neuroplasticity [93] and antioxidant properties of $A \beta$ and tau [32], a chronically high demand for plasticity-related activity upregulates the level of tau and $A \beta$. Experimental evidence has already shown that high levels of plasticity are associated with increased expression and phosphorylation of tau [174] and APP levels [90]. The resultant P-tau polymerizes to NFT leading to cytoskeletal dysfunction and neuronal degeneration while toxic $A \beta$ species themselves can produce synaptic damage and cell death directly [175]. The adjacent neurons would now be facing the plasticity demand and the process continues and 
gradually extends to tightly linked adjacent areas of the limbic-paralimbic cortex, resulting in horizontal spread of NFT [176], reasoning the early and prominent involvement of the limbic system out. The loss of limbic neurons now places the plasticity burden on the reciprocally connected association areas, resulting in accumulation of NFTs which spread vertically as well as centrifugally [176], thus gradually involving adjacent regions and accounting for the anatomical cascade in $\mathrm{AD}$.

\section{Interindividual Variation}

Along with the pathogenesis, even the clinical manifestations remain an enigma. Age at presentation varies broadly in case of $\mathrm{AD}$, with EOAD manifesting roughly between 30-60 years and LOAD after 60 years. Even patients with extensive pathological lesions in the brain have remained cognitively normal [177], and about $20-40 \%$ of cognitively normal elderly people have evidence of significant brain $A \beta$ plaque deposition [178]. The clue stems from the fact that even in patients with established $\mathrm{AD}$ mutations, onset age varies. Although convincing proof is yet to be established, the concept of a 'cognitive reserve (CR)' could provide an explanation. According to the CR model, the brain actively attempts to cope with brain damage using preexisting cognitive processing approaches or utilizing compensatory approaches [179] altering neuroplasticity. Thus, the same amount of brain damage or pathology may have different effects on different people, even if brain size remains constant. As a result, individuals with more $C R$ would be more successful at coping with the same amount of brain damage [180]. Apart from the CR, 4 alternate splice variants are found for BACE [181], hence the differential expression of the variant secretase can differ in APP processing and modulate the rate of $A \beta$ production and contribute to the interindividual variation [6]. It is not known whether individual differences in the antioxidant reserve exist and if they do, whether they contribute to interpatient differences.

\section{Integrated Pathomechanism}

Although the individual mechanisms are well established, an integrated cascade remains to be proven. Jack et al. [6] observed biomarkers in AD and found that (1) the biomarkers become abnormal in a temporally ordered manner with progressing disease, (2) A $\beta$-plaque biomarkers are dynamic early in the disease, before the appearance of clinical symptoms (3) biomarkers of neuronal injury, dysfunction and degeneration present later in disease and correlate with clinical symptom severity, (4) NFT accumulation and cerebral atrophy, spread from medial temporal limbic areas to adjacent limbic and paralimbic areas, and later to the isocortical association cortex, and (5) a lag phase of unknown duration is present between $A \beta$ plaque formation and the neurodegenerative cascade. Considering the above findings in mind, some assumptions can be derived, which might give orientation for future proceedings although hypothetical (fig. 2).

The finding that markers of $A \beta$ formation present before clinical features [6] indicates that $A \beta$ is crucial in the pathogenesis of $A D$ and the time taken for $A \beta$ accumulation decides the age of disease onset. In case of sporadic $\mathrm{AD}$, the process of $\mathrm{A} \beta$ production is rather complex and involves multiple deregulated mechanisms; however, it is difficult to say convincingly as to which process is the earliest to be perturbed. The $A \beta$ accumulation occurs over years, probably decades, accounting for the late manifestation of sporadic AD. This is substantiated by the fact that EOAD occurs in patients with mutations in APP or PSEN, for example, resulting in increased $A \beta$ accumulation. In ApoE $\varepsilon 4$ carriers, there is decreased $A \beta$ clearance and neuroinflammation [112] accounting for early $A \beta$ accumulation. The left shift in the $A \beta$ accumulation curve [6] accounts for the early manifestation of the disease.

Preclinical AD corresponds to the asymptomatic period during which the disease process continues subtly. During this phase, disease process remains confined to the hippocampus/limbic cortex, rather than the CNS in general. In response to the perturbations, neurons adopt a compensated state maintaining plasticity, during which there is $A \beta$ production. The individual stressor in this case is rather weak, but with more and more abnormal mechanisms stepping in, there is amplified $A \beta$ production. Neuropathological studies in preclinical AD have shown that there is $A \beta$ accumulation in the brain although in the absence of significant global OXS, probably due to the lack of $A \beta$ oligomerization [182]. In addition, there is no significant increase in the protein carbonyl content but rather neuronal hypertrophy, along with nuclei and nucleolar hypertrophy [183]. The exact nature of this adaptation and its resilience over time is uncertain, but indicates the compensatory response of neurons, representing the resistance displayed by the neurons to survive the stressors, which could last a definite but variable period before the onset of cognitive decline.

The stage of neurodegeneration encompasses $\mathrm{MCI}$ and dementia, and occurs due to synaptic loss and neuronal 
Fig. 2. Hypothetical pathophysiological cascade in $\mathrm{AD} .{ }^{*}=$ Addition of a new mechanism into the pathway; ETC = electron transport chain; $-{ }_{-}=$the period of decline in neuronal function.

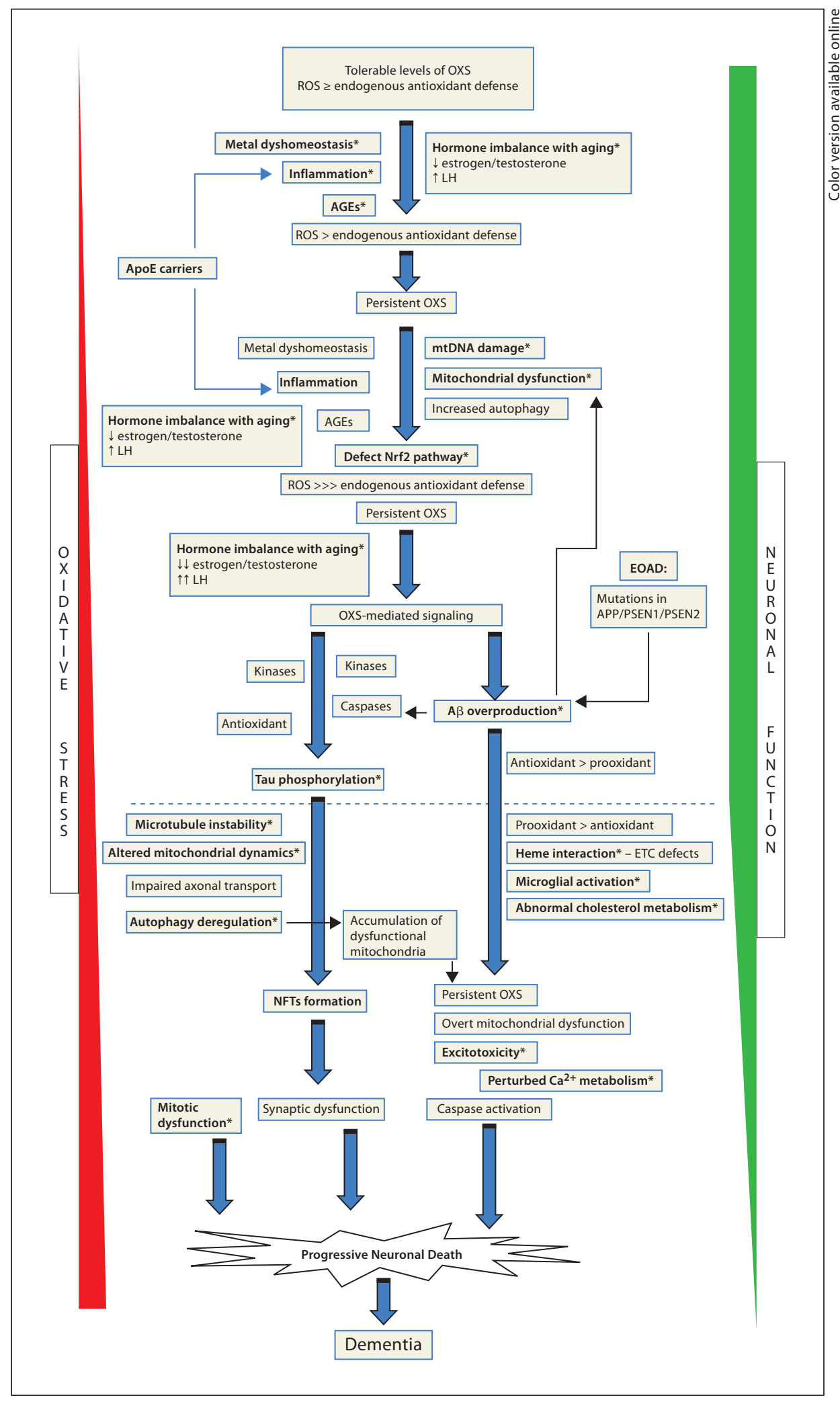


death gradually leading to atrophy. The findings observed during this stage were again in temporal order with decreased metabolism shown in fluorodeoxy glucose positron emission tomography occurring first, followed by increased CSF-tau and brain atrophy in MRI [6]. This part of the pathophysiology is probably common to both EOAD and LOAD. MCI, a state between normality and fullblown $\mathrm{AD}$, represents a stage of transition from normality and heralds a rapid decline in neuronal function. Many patients with the clinical syndrome of MCI presented the 'AD pattern' of hypometabolism in temporoparietal regions [184], which predicts progression to clinical AD.

Only few longitudinal neuropathological studies on clinically diagnosed MCI are available, and some common features are reported. Between preclinical AD and $\mathrm{MCI}$, a significant increase in the level of protein carbonyls, indicative of significantly elevated oxidative stress in MCI has been observed despite equal levels of pathology [185]. Specifically, carbonylation of heat shock protein (HSP90) was significantly increased and levels of ubiquitin carboxyl-terminal esterase L1 (UCLH1) were decreased in MCI compared to preclinical $\mathrm{AD}$ and controls [185], indicating the onset of proteosomal dysfunction that was normal in preclinical AD. Patients with MCI showed significantly increased neuritic plaques in all neocortical regions and the amygdala compared with controls. NFTs were significantly increased in the amygdala, entorhinal cortex, CA1, subiculum and inferior parietal lobule in MCI compared with normal controls [186]. Neuritic plaques were increased in the amygdala and subiculum, and NFTs were significantly increased in middle frontal and middle temporal gyri, amygdala and subiculum in EOAD compared with MCI [186]. In a longitudinal study by Scheff et al. [187], synapse numbers were decreased by $18 \%$ in the stratum radiation of hippocampal CA1 and $13 \%$ in the outer molecular layer of the dentate gyrus in MCI patients compared with normal controls but did not reach statistical significance. However, comparing $\mathrm{MCI}$ to $\mathrm{AD}$, synapse number was significantly decreased in $\mathrm{AD}$ by $44 \%$ in the outer molecular layer and $55 \%$ in the stratum radiation. Thus, $\mathrm{AD}$ pathology is much greater in MCI patients than in controls, but it is intermediate between controls and AD.

Pathophysiologically, it is during this phase that the disease process begins to dominate compensatory mechanisms. As discussed earlier, oligomerized $A \beta$ is probably the major culprit in this stage and worsens neuronal function via multiple mechanisms. The failure of antioxidant defense mechanisms reflected by improper Nrf2 localization [11] in the nucleus also plays a role in $\mathrm{AD}$ pathogenesis. The levels of $A \beta$ degrading enzymes are decreased in $A D$, and $A \beta$ begins to accumulate with the $A \beta$ production exceeding its clearance. In fact, $A \beta$ can directly induce synaptic damage and neuronal apoptosis, resulting in accelerated neuronal death placing additional plasticity demand on the surviving neurons that fail to cope with. Tau phosphorylation probably reflects the neuronal attempt to maintain plasticity. However, P-tau, due to its tendency to aggregate, develops into NFTs, further impairing neurogenesis. Subsequently, both $A \beta$ and $\mathrm{P}$-tau individually as well as synergistically produce neuronal degeneration and death. Various other mechanisms, such as perturbed cholesterol metabolism, mitotic dysfunction or caspase activation, also contribute to the neuronal decline and death.

This process propagates to nearby and associated regions; initially, it is limited to entorhinal cortices, spreading to temporoparietal association cortices, and then to frontal and, ultimately, to primary sensory and visual areas $[162,163]$. This sequential involvement suggests that at a particular time period, different sites of the brain might be in different phases of the disease. The patient might be asymptomatic for a variable period during this phase depending on the individual's CR. Once a particular threshold is reached beyond CR, it manifests as memory deficits and MCI, and later progresses to dementia.

\section{Conclusion and Future Directions}

Thus, the pathophysiology of AD is enigmatic and puzzling, and further studies are needed to bring the complete picture. Our failure to understand the temporal sequence of events is probably the reason for our failure in various treatment trials. For instance, inflammation plays an important role in the early phases of the disease; hence and rightfully, various treatment trials with nonsteroidal anti-inflammatory drugs have failed. Considering age-related neuronal loss and plasticity changes, it is possible that every individual might develop AD with advancing age, but the interperson variation in antioxidant reserve, APP processing, neuronal adaptations and CR affect the age of $\mathrm{AD}$ onset, and at least theoretically every individual might develop AD in due course if they survive. If proven that $\mathrm{OXS}$ is the main trigger of $\mathrm{AD}$, prevention of $A D$ might have to be taken to the primordial prevention level beginning with diet and exercise.

The precise reason for early hippocampal involvement and sparing of other regions is still not clear. Autopsy studies may be planned in different age groups, studying 
the integrity of individual mechanisms throughout the course of AD in order to define the disease cascade. Sorting out the disease cascade will only help us in devising specific screening or diagnostic tests for $\mathrm{AD}$ and in guiding specific management. Proteomic studies elucidating the differential expression of proteins at various sites in the brain could explain the site-specific involvement in AD. Although preventive trials with neuroprotective strategies in the general public might raise ethical concerns, they can be planned and might be done in ApoE $\varepsilon 4$ carriers to demonstrate possible benefits.

\section{Disclosure Statement}

The authors have no conflict of interest to declare.

\section{References}

1 Alzheimer's Association: 2008 Alzheimer's disease facts and figures. Alzheimers Dement 2008;4:110-133.

- 2 Ferri CP, Prince M, Brayne C, Brodaty $\mathrm{H}$ Fratiglioni L, Ganguli M, Hall K, Hasegawa $\mathrm{K}$, Hendrie H, Huang Y, Jorm A, Mathers C, Menezes PR, Rimmer E, Scazufca M: Global prevalence of dementia: a Delphi consensus study. Lancet 2005;366:2112-2117.

-3 Ziegler-Graham K, Brookmeyer R, Johnson E, Arrighi HM: Worldwide variation in the doubling time of Alzheimer's disease incidence rates. Alzheimers Dement 2008;4:316-323.

-4 Kivipelto M, Helkala EL, Laakso MP, Hanninen T, Hallikainen M, Alhainen K, Soininen H, Tuomilehto J, Nissinen A: Midlife vascular risk factors and Alzheimer's disease in later life: longitudinal, population based study. BMJ 2001;322:1447-1451.

5 Bekris LM, Yu CE, Bird TD, Tsuang DW: Genetics of Alzheimer disease. J Geriatr Psychiatry Neurol 2010;23:213-227.

-6 Jack CR Jr, Knopman DS, Jagust WJ, Shaw LM, Aisen PS, Weiner MW, Petersen RC, Trojanowski JQ: Hypothetical model of dynamic biomarkers of the Alzheimer's pathological cascade. Lancet Neurol 2010;9:119-128.

-7 Zhu X, Su B, Wang X, Smith M, Perry G: Causes of oxidative stress in Alzheimer disease. Cell Mol Life Sci 2007;64:2202-2210.

$\checkmark 8$ Zhu X, Raina AK, Lee HG, Casadesus G, Smith MA, Perry G: Oxidative stress signalling in Alzheimer's disease. Brain Res 2004; 1000:32-39.

$\checkmark 9$ Zhu X, Lee HG, Perry G, Smith MA: Alzheimer disease, the two-hit hypothesis: an update. Biochim Biophys Acta 2007;1772:494502

10 Small DH: Dysregulation of calcium homeostasis in Alzheimer's disease. Neurochem Res 2009;34:1824-1829.

-11 Ramsey CP, Glass CA, Montgomery MB, Lindl KA, Ritson GP, Chia LA, Hamilton RL, Chu CT, Jordan-Sciutto KL: Expression of Nrf2 in neurodegenerative diseases. J Neuropathol Exp Neurol 2007;66:75-85.

$\checkmark 12$ Koutsilieri E, Riederer P: Excitotoxicity and new antiglutamatergic strategies in Parkinson's disease and Alzheimer's disease. Parkinsonism Relat Disord 2007;13(suppl 3): S329-S331.
13 Kincses ZT, Toldi J, Vecsei L: Kynurenines, neurodegeneration and Alzheimer's disease. J Cell Mol Med 2010;14:2045-2054.

14 Kim J, Basak JM, Holtzman DM: The role of apolipoprotein E in Alzheimer's disease. Neuron 2009;63:287-303.

15 Kalaria RN: Microglia and Alzheimer's dis ease. Curr Opin Hematol 1999;6:15.

16 Fonseca AC, Resende R, Oliveira CR, Pereira CM: Cholesterol and statins in Alzheimer's disease: current controversies. Exp Neurol 2010;223:282-293.

17 Bezprozvanny I: Calcium signaling and neurodegenerative diseases. Trends $\mathrm{Mol} \mathrm{Med}$ 2009; 15:89-100.

18 Atwood CS, Obrenovich ME, Liu T, Chan $\mathrm{H}$ Perry G, Smith MA, Martins RN: Amyloidbeta: a chameleon walking in two worlds: a review of the trophic and toxic properties of amyloid-beta. Brain Res Brain Res Rev 2003 43:1-16.

19 Lahiri DK, Zawia NH, Greig NH, Sambamurti K, Maloney B: Early-life events may trigger biochemical pathways for Alzheimer's disease: the 'learn' model. Biogerontology 2008;9:375-379.

20 Lovell MA, Robertson JD, Teesdale WJ, Campbell JL, Markesbery WR: Copper, iron and zinc in Alzheimer's disease senile plaques. J Neurol Sci 1998; 158:47-52.

21 Smith MA, Harris PL, Sayre LM, Perry G: Iron accumulation in Alzheimer disease is a source of redox-generated free radicals. Proc Natl Acad Sci USA 1997;94:9866-9868.

22 Evans PH, Klinowski J, Yano E, Urano N Alzheimer's disease: a pathogenic role for aluminosilicate-induced phagocytic free radicals. Free Radic Res Commun 1989;6: 317-321.

23 Bondy SC, Guo-Ross SX, Truong AT: Promotion of transition metal-induced reactive oxygen species formation by beta-amyloid. Brain Res 1998;799:91-96.

24 Yan SD, Yan SF, Chen X, Fu J, Chen M, Kup pusamy P, Smith MA, Perry G, Godman GC Nawroth P, et al: Non-enzymatically glycated tau in Alzheimer's disease induces neuronal oxidant stress resulting in cytokine gene expression and release of amyloid beta-pep tide. Nat Med 1995;1:693-699.
25 Yan SD, Chen X, Fu J, Chen M, Zhu H, Roher A, Slattery T, Zhao L, Nagashima M, Morser J, Migheli A, Nawroth P, Stern D, Schmidt AM: RAGE and amyloid-beta peptide neurotoxicity in Alzheimer's disease. Nature 1996; 382:685-691.

-26 El Khoury J, Hickman SE, Thomas CA, Cao L, Silverstein SC, Loike JD: Scavenger receptor-mediated adhesion of microglia to betaamyloid fibrils. Nature 1996;382:716-719.

-27 Keller JN, Gee J, Ding Q: The proteasome in brain aging. Ageing Res Rev 2002;1:279293

28 Brunk UT, Terman A: The mitochondriallysosomal axis theory of aging: accumulation of damaged mitochondria as a result of imperfect autophagocytosis. Eur J Biochem 2002;269:1996-2002.

-29 Zhang W, Lei ZM, Rao CV: Immortalized hippocampal cells contain functional luteinizing hormone/human chorionic gonadotropin receptors. Life Sci 1999;65:20832098.

- 30 Van Muiswinkel FL, Veerhuis R, Eikelenboom P: Amyloid beta protein primes cultured rat microglial cells for an enhanced phorbol 12-myristate 13-acetate-induced respiratory burst activity. J Neurochem 1996; 66:2468-2476.

- 31 Klegeris A, McGeer PL: Beta-amyloid protein enhances macrophage production of oxygen free radicals and glutamate. J Neurosci Res 1997;49:229-235.

- 32 Smith MA, Casadesus G, Joseph JA, Perry G: Amyloid-beta and tau serve antioxidant functions in the aging and Alzheimer brain. Free Radic Biol Med 2002;33:1194-1199.

- 33 Varadarajan S, Yatin S, Aksenova M, Butterfield DA: Review: Alzheimer's amyloid betapeptide-associated free radical oxidative stress and neurotoxicity. J Struct Biol 2000; 130:184-208

-34 Kontush A, Berndt C, Weber W, Akopyan V, Arlt S, Schippling S, Beisiegel U: Amyloidbeta is an antioxidant for lipoproteins in cerebrospinal fluid and plasma. Free Radic Biol Med 2001;30:119-128.

35 Behl C, Davis JB, Lesley R, Schubert D: Hydrogen peroxide mediates amyloid beta protein toxicity. Cell 1994;77:817-827. 
-36 Mark RJ, Lovell MA, Markesbery WR, Uchida K, Mattson MP: A role for 4-hydroxynonenal, an aldehydic product of lipid peroxidation, in disruption of ion homeostasis and neuronal death induced by amyloid betapeptide. J Neurochem 1997;68:255-264.

37 Xu J, Chen S, Ahmed SH, Chen H, Ku G, Goldberg MP, Hsu CY: Amyloid-beta peptides are cytotoxic to oligodendrocytes. J Neurosci 2001;21:RC118.

38 Mark RJ, Pang Z, Geddes JW, Uchida K, Mattson MP: Amyloid beta-peptide impairs glucose transport in hippocampal and cortical neurons: involvement of membrane lipid peroxidation. J Neurosci 1997; 17:10461054.

- 39 Atamna H, Boyle K: Amyloid-beta peptide binds with heme to form a peroxidase: relationship to the cytopathologies of Alzheimer's disease. Proc Natl Acad Sci USA 2006; 103:3381-3386.

40 Atamna H, Frey WH 2nd: Mechanisms of mitochondrial dysfunction and energy deficiency in Alzheimer's disease. Mitochondrion 2007;7:297-310.

41 Gibson GE, Sheu KF, Blass JP: Abnormalities of mitochondrial enzymes in Alzheimer disease. J Neural Transm 1998;105:855-870.

42 Parker WD Jr, Mahr NJ, Filley CM, Parks JK, Hughes D, Young DA, Cullum CM: Reduced platelet cytochrome $\mathrm{c}$ oxidase activity in Alzheimer's disease. Neurology 1994;44: 1086-1090.

-43 Parker WD Jr, Parks J, Filley CM, Kleinschmidt-DeMasters BK: Electron transport chain defects in Alzheimer's disease brain. Neurology 1994;44:1090-1096.

44 Coskun PE, Beal MF, Wallace DC: Alzheimer's brains harbor somatic mtDNA controlregion mutations that suppress mitochondrial transcription and replication. Proc Natl Acad Sci USA 2004;101:10726-10731.

-45 Corral-Debrinski M, Horton T, Lott MT, Shoffner JM, McKee AC, Beal MF, Graham $\mathrm{BH}$, Wallace DC: Marked changes in mitochondrial DNA deletion levels in Alzheimer brains. Genomics 1994;23:471-476.

-46 Zhu X, Perry G, Moreira PI, Aliev G, Cash AD, Hirai K, Smith MA: Mitochondrial abnormalities and oxidative imbalance in Alzheimer disease. J Alzheimers Dis 2006;9: 147-153.

47 Wang X, Su B, Lee HG, Li X, Perry G, Smith MA, Zhu X: Impaired balance of mitochondrial fission and fusion in Alzheimer's disease. J Neurosci 2009;29:9090-9103.

48 Wu Y, Sun FF, Tong DM, Taylor BM: Changes in membrane properties during energy depletion-induced cell injury studied with fluorescence microscopy. Biophys J 1996;71:91-100.

49 Kaether C, Haass C: A lipid boundary separates APP and secretases and limits amyloid beta-peptide generation. J Cell Biol 2004;167: 809-812.

- 50 Perry G, Nunomura A, Smith MA: A suicide note from Alzheimer disease neurons? Nat Med 1998;4:897-898.
51 Wiese AG, Pacifici RE, Davies KJ: Transient adaptation of oxidative stress in mammalian cells. Arch Biochem Biophys 1995;318:231240.

52 Itoh K, Chiba T, Takahashi S, Ishii T, Igarashi K, Katoh Y, Oyake T, Hayashi N, Satoh K, Hatayama I, Yamamoto M, Nabeshima Y: An Nrf2/small Maf heterodimer mediates the induction of phase II detoxifying enzyme genes through antioxidant response elements. Biochem Biophys Res Commun 1997; 236:313-322.

53 Itoh K, Wakabayashi N, Katoh Y, Ishii T, Igarashi K, Engel JD, Yamamoto M: Keapl represses nuclear activation of antioxidant responsive elements by Nrf2 through binding to the amino-terminal Neh2 domain. Genes Dev 1999;13:76-86.

54 Dinkova-Kostova AT, Holtzclaw WD, Cole RN, Itoh K, Wakabayashi N, Katoh Y, Yamamoto M, Talalay P: Direct evidence that sulfhydryl groups of Keap1 are the sensors regulating induction of phase 2 enzymes that protect against carcinogens and oxidants. Proc Natl Acad Sci USA 2002;99:11908-11913.

55 Zipper LM, Mulcahy RT: The Keap1 BTB/ $\mathrm{POZ}$ dimerization function is required to sequester Nrf2 in cytoplasm. J Biol Chem 2002; 277:36544-36552.

- 56 Kwak MK, Itoh K, Yamamoto M, Sutter TR, Kensler TW: Role of transcription factor Nrf2 in the induction of hepatic phase 2 and antioxidative enzymes in vivo by the cancer chemoprotective agent, 3H-1, 2-dimethiole3-thione. Mol Med 2001;7:135-145.

57 Calkins MJ, Jakel RJ, Johnson DA, Chan K, Kan YW, Johnson JA: Protection from mitochondrial complex II inhibition in vitro and in vivo by Nrf2-mediated transcription. Proc Natl Acad Sci USA 2005;102:244-249.

-58 Kraft AD, Johnson DA, Johnson JA: Nuclear factor E2-related factor 2-dependent antioxidant response element activation by tert-butylhydroquinone and sulforaphane occurring preferentially in astrocytes conditions neurons against oxidative insult. J Neurosci 2004;24:1101-1112.

59 Roux PP, Blenis J: Erk and p38 MAPK-activated protein kinases: a family of protein kinases with diverse biological functions. Microbiol Mol Biol Rev 2004;68:320-344.

60 Zhu X, Rottkamp CA, Boux H, Takeda A, Perry G, Smith MA: Activation of 38 kinase links tau phosphorylation, oxidative stress, and cell cycle-related events in Alzheimer disease. J Neuropathol Exp Neurol 2000;59:880-888.

-61 Veeranna, Amin ND, Ahn NG, Jaffe H, Winters CA, Grant P, Pant HC: Mitogen-activated protein kinases $($ Erk1,2) phosphorylate Lys-Ser-Pro (KSP) repeats in neurofilament proteins NF-H and NF-M. J Neurosci 1998; 18:4008-4021.

62 Yoshida H, Hastie CJ, McLauchlan H, Cohen P, Goedert M: Phosphorylation of microtubule-associated protein tau by isoforms of cJun N-terminal kinase (JNK). J Neurochem 2004;90:352-358.
63 Reynolds CH, Nebreda AR, Gibb GM, Utton MA, Anderton BH: Reactivating kinase/p38 phosphorylates tau protein in vitro. J Neurochem 1997;69:191-198.

64 Mandelkow EM, Drewes G, Biernat J, Gustke N, Van Lint J, Vandenheede JR, Mandelkow E: Glycogen synthase kinase-3 and the Alzheimer-like state of microtubule-associated protein tau. FEBS Lett 1992;314:315-321.

- 65 Patrick GN, Zukerberg L, Nikolic M, de la Monte S, Dikkes P, Tsai LH: Conversion of p35 to p25 deregulates Cdk5 activity and promotes neurodegeneration. Nature 1999; 402:615-622.

66 Li G, Yin H, Kuret J: Casein kinase 1 delta phosphorylates tau and disrupts its binding to microtubules. J Biol Chem 2004;279: 15938-15945.

67 Jicha GA, Weaver C, Lane E, Vianna C, Kress Y, Rockwood J, Davies P: cAMP-dependent protein kinase phosphorylations on tau in Alzheimer's disease. J Neurosci 1999;19: 7486-7494.

68 Steiner B, Mandelkow EM, Biernat J, Gustke N, Meyer HE, Schmidt B, Mieskes G, Soling HD, Drechsel D, Kirschner MW, et al: Phosphorylation of microtubule-associated protein tau: identification of the site for $\mathrm{Ca}^{2+}$ calmodulin dependent kinase and relationship with tau phosphorylation in Alzheimer tangles. EMBO J 1990;9:3539-3544.

-69 Rissman RA, Poon WW, Blurton-Jones M, Oddo S, Torp R, Vitek MP, LaFerla FM, Rohn TT, Cotman CW: Caspase-cleavage of tau is an early event in Alzheimer disease tangle pathology. J Clin Invest 2004;114:121-130.

70 Shoji M, Iwakami N, Takeuchi S, Waragai M, Suzuki M, Kanazawa I, Lippa CF, Ono S, Okazawa $\mathrm{H}$ : JNK activation is associated with intracellular beta-amyloid accumulation. Brain Res Mol Brain Res 2000;85:221233.

71 Morishima Y, Gotoh Y, Zieg J, Barrett T, Takano H, Flavell R, Davis RJ, Shirasaki Y, Greenberg ME: Beta-amyloid induces neuronal apoptosis via a mechanism that involves the c-Jun $\mathrm{N}$-terminal kinase pathway and the induction of Fas ligand. J Neurosci 2001;21:7551-7560.

72 Troy CM, Rabacchi SA, Xu Z, Maroney AC, Connors TJ, Shelanski ML, Greene LA: Betaamyloid-induced neuronal apoptosis requires c-Jun $\mathrm{N}$-terminal kinase activation. J Neurochem 2001;77:157-164.

73 Su B, Wang X, Nunomura A, Moreira PI, Lee HG, Perry G, Smith MA, Zhu X: Oxidative stress signaling in Alzheimer's disease. Curr Alzheimer Res 2008;5:525-532.

74 Hussain I, Powell D, Howlett DR, Tew DG, Meek TD, Chapman C, Gloger IS, Murphy KE, Southan CD, Ryan DM, Smith TS, Simmons DL, Walsh FS, Dingwall C, Christie G: Identification of a novel aspartic protease (Asp 2) as beta-secretase. Mol Cell Neurosci 1999;14:419-427. 
75 Tamagno E, Bardini P, Obbili A, Vitali A, Borghi R, Zaccheo D, Pronzato MA, Danni O, Smith MA, Perry G, Tabaton M: Oxidative stress increases expression and activity of BACE in NT2 neurons. Neurobiol Dis 2002;10:279-288.

76 Hogervorst E, Bandelow S, Combrinck M, Smith AD: Low free testosterone is an independent risk factor for Alzheimer's disease. Exp Gerontol 2004;39:1633-1639.

77 Manly JJ, Merchant CA, Jacobs DM, Small SA, Bell K, Ferin M, Mayeux R: Endogenous estrogen levels and Alzheimer's disease among postmenopausal women. Neurology 2000;54:833-837.

78 Dimayuga FO, Reed JL, Carnero GA, Wang C, Dimayuga ER, Dimayuga VM, Perger A, Wilson ME, Keller JN, Bruce-Keller AJ: Estrogen and brain inflammation: effects on microglial expression of $\mathrm{MHC}$, costimulatory molecules and cytokines. J Neuroimmunol 2005;161:123-136.

79 Jaffe AB, Toran-Allerand CD, Greengard P, Gandy SE: Estrogen regulates metabolism of Alzheimer amyloid beta precursor protein. J Biol Chem 1994;269:13065-13068.

>80 Panizzon MS, Hauger R, Dale AM, Eaves LJ, Eyler LT, Fischl B, Fennema-Notestine C, Franz CE, Grant MD, Jak AJ, Jacobson KC, Lyons MJ, Mendoza SP, Neale MC, PromWormley EC, Seidman LJ, Tsuang MT, Xian $\mathrm{H}$, Kremen WS: Testosterone modifies the effect of APOE genotype on hippocampal volume in middle-aged men. Neurology 2010;75:874-880.

-81 Bowen RL, Isley JP, Atkinson RL: An association of elevated serum gonadotropin concentrations and Alzheimer disease? J Neuroendocrinol 2000;12:351-354.

82 Bowen RL, Smith MA, Harris PL, Kubat Z, Martins RN, Castellani RJ, Perry G, Atwood CS: Elevated luteinizing hormone expression colocalizes with neurons vulnerable to $\mathrm{Alz}$ heimer's disease pathology. J Neurosci Res 2002;70:514-518.

-83 Bowen RL, Verdile G, Liu T, Parlow AF, Perry G, Smith MA, Martins RN, Atwood CS: Luteinizing hormone, a reproductive regulator that modulates the processing of amyloid-beta precursor protein and amyloid-beta deposition. J Biol Chem 2004;279:20539-20545.

-84 Bukovsky A, Indrapichate K, Fujiwara H, Cekanova M, Ayala ME, Dominguez R, Caudle MR, Wimalsena J, Elder RF, Copas P, Foster JS, Fernando RI, Henley DC, Upadhyaya NB: Multiple luteinizing hormone receptor (LHR) protein variants, interspecies reactivity of anti-LHR mAb clone 3B5, subcellular localization of LHR in human placenta, pelvic floor and brain, and possible role for LHR in the development of abnormal pregnancy, pelvic floor disorders and Alzheimer's disease. Reprod Biol Endocrinol 2003;1:46.
85 Shirai F, Kawaguchi M, Yutsudo M, Dohi Y: Human peripheral blood polymorphonuclear leukocytes at the ovulatory period are in an activated state. Mol Cell Endocrinol 2002; 196:21-28

86 Seubert P, Vigo-Pelfrey C, Esch F, Lee M, Dovey H, Davis D, Sinha S, Schlossmacher M, Whaley J, Swindlehurst C, et al: Isolation and quantification of soluble Alzheimer's beta-peptide from biological fluids. Nature 1992;359:325-327.

87 Nunomura A, Perry G, Pappolla MA, Friedland RP, Hirai K, Chiba S, Smith MA: Neuronal oxidative stress precedes amyloid-beta deposition in Down syndrome. J Neuropathol Exp Neurol 2000;59:1011-1017.

88 Nunomura A, Perry G, Aliev G, Hirai K, Takeda A, Balraj EK, Jones PK, Ghanbari H, Wataya T, Shimohama S, Chiba S, Atwood CS, Petersen RB, Smith MA: Oxidative damage is the earliest event in Alzheimer disease. J Neuropathol Exp Neurol 2001;60:759-767.

89 Smith MA, Rottkamp CA, Nunomura A, Raina AK, Perry G: Oxidative stress in Alzheimer's disease. Biochim Biophys Acta 2000;1502:139-144.

90 Wallace W, Ahlers ST, Gotlib J, Bragin V, Sugar J, Gluck R, Shea PA, Davis KL, Haroutunian V: Amyloid precursor protein in the cerebral cortex is rapidly and persistently induced by loss of subcortical innervation. Proc Natl Acad Sci USA 1993;90:8712-8716.

91 Wallace WC, Akar CA, Lyons WE: Amyloid precursor protein potentiates the neurotrophic activity of NGF. Mol Brain Res 1997; 52:201-212.

92 Jan A, Adolfsson O, Allaman I, Buccarello A-L, Magistretti PJ, Pfeifer A, Muhs A, Lashuel HA: A $\beta 42$ neurotoxicity is mediated by ongoing nucleated polymerization process rather than by discrete $A \beta 42$ species. J Biol Chem 2011;286:8585-8596.

93 Buee L, Bussiere T, Buee-Scherrer V, Delacourte A, Hof PR: Tau protein isoforms, phosphorylation and role in neurodegenerative disorders. Brain Res Brain Res Rev 2000; 33:95-130.

94 Takeda A, Smith MA, Avila J, Nunomura A, Siedlak SL, Zhu X, Perry G, Sayre LM: In Alzheimer's disease, heme oxygenase is coincident with Alz50, an epitope of tau induced by 4-hydroxy-2-nonenal modification. J Neurochem 2000;75:1234-1241.

$\checkmark 95$ Morsch R, Simon W, Coleman PD: Neurons may live for decades with neurofibrillary tangles. J Neuropathol Exp Neurol 1999;58: 188-197.

$\$ 96$ Wataya T, Nunomura A, Smith MA, Siedlak SL, Harris PL, Shimohama S, Szweda LI, Kaminski MA, Avila J, Price DL, Cleveland DW, Sayre LM, Perry G: High molecular weight neurofilament proteins are physiological substrates of adduction by the lipid peroxidation product hydroxynonenal. J Biol Chem 2002;277:4644-4648.
97 Moreira PI, Nunomura A, Zhu X, Lee HG, Aliev G, Smith MA, Perry G: Alzheimer disease: oxidative stress and compensatory responses; in Veasey SC (ed): Oxidative Neural Injury. Dordrecht, Humana Press, 2009, pp 109-120.

98 Hamdane M, Delobel P, Sambo AV, Smet C, Begard S, Violleau A, Landrieu I, Delacourte A, Lippens G, Flament S, Buee L: Neurofibrillary degeneration of the Alzheimer-type: an alternate pathway to neuronal apoptosis? Biochem Pharmacol 2003; 66:1619-1625.

\$9 Garcia ML, Cleveland DW: Going new places using an old map: tau, microtubules and human neurodegenerative disease. Curr Opin Cell Biol 2001;13:41-48.

100 Pfrieger FW: Outsourcing in the brain: Do neurons depend on cholesterol delivery by astrocytes? Bioessays 2003;25:72-78.

101 Koudinov AR, Koudinova NV: Essential role for cholesterol in synaptic plasticity and neuronal degeneration. FASEB J 2001; 15:1858-1860.

102 Yaffe K, Barrett-Connor E, Lin F, Grady D: Serum lipoprotein levels, statin use, and cognitive function in older women. Arch Neurol 2002;59:378-384.

103 Wolf H, Hensel A, Arendt T, Kivipelto M, Winblad B, Gertz HJ: Serum lipids and hippocampal volume: the link to Alzheimer's disease? Ann Neurol 2004;56:745-748.

104 Corder EH, Saunders AM, Strittmatter WJ, Schmechel DE, Gaskell PC, Small GW, Roses AD, Haines JL, Pericak-Vance MA: Gene dose of apolipoprotein E type 4 allele and the risk of Alzheimer's disease in late onset families. Science 1993;261:921-923.

105 Simons M, Keller P, De Strooper B, Beyreuther K, Dotti CG, Simons K: Cholesterol depletion inhibits the generation of beta-amyloid in hippocampal neurons. Proc Natl Acad Sci USA 1998;95:6460-6464.

106 Refolo LM, Malester B, LaFrancois J, Bryant-Thomas T, Wang R, Tint GS, Sambamurti K, Duff K, Pappolla MA: Hypercholesterolemia accelerates the Alzheimer's amyloid pathology in a transgenic mouse model. Neurobiol Dis 2000;7:321-331.

107 Igbavboa U, Pidcock JM, Johnson LN, Malo TM, Studniski AE, Yu S, Sun GY, Wood WG: Cholesterol distribution in the Golgi complex of DITNC1 astrocytes is differentially altered by fresh and aged amyloid beta-peptide-(1-42). J Biol Chem 2003;278: 17150-17157.

108 Koudinov AR, Koudinova NV: Cholesterol homeostasis failure as a unifying cause of synaptic degeneration. J Neurol Sci 2005; 229-230:233-240.

109 Cutler RG, Kelly J, Storie K, Pedersen WA, Tammara A, Hatanpaa K, Troncoso JC, Mattson MP: Involvement of oxidative stress-induced abnormalities in ceramide and cholesterol metabolism in brain aging and Alzheimer's disease. Proc Natl Acad Sci USA 2004;101:2070-2075. 
110 Martel CL, Mackic JB, Matsubara E, Governale S, Miguel C, Miao W, McComb JG, Frangione B, Ghiso J, Zlokovic BV: Isoform-specific effects of apolipoproteins E2, E3, and E4 on cerebral capillary sequestration and blood-brain barrier transport of circulating Alzheimer's amyloid beta. J Neurochem 1997;69:1995-2004.

-111 Bales KR, Verina T, Dodel RC, Du Y, Altstiel L, Bender M, Hyslop P, Johnstone EM, Little SP, Cummins DJ, Piccardo P, Ghetti B, Paul SM: Lack of apolipoprotein E dramatically reduces amyloid beta-peptide deposition. Nat Genet 1997;17:263-264.

- 112 Lichtenstein MP, Carriba P, Masgrau R, Pujol A, Galea E: Staging anti-inflammatory therapy in Alzheimer's disease. Front Aging Neurosci 2010;2:142.

113 Vitek MP, Brown CM, Colton CA: APOE genotype-specific differences in the innate immune response. Neurobiol Aging 2009; 30:1350-1360.

114 Zhong N, Ramaswamy G, Weisgraber KH: Apolipoprotein E4 domain interaction induces endoplasmic reticulum stress and impairs astrocyte function. J Biol Chem 2009;284:27273-27280.

-115 Nelson TJ, Alkon DL: Oxidation of cholesterol by amyloid precursor protein and beta-amyloid peptide. J Biol Chem 2005;280: 7377-7387.

- 116 Jacob CP, Koutsilieri E, Bartl J, Neuen-Jacob E, Arzberger T, Zander N, Ravid R, Roggendorf W, Riederer P, Grunblatt E: Alterations in expression of glutamatergic transporters and receptors in sporadic Alzheimer's disease. J Alzheimers Dis 2007; 11:97-116.

-117 Rissman RA, De Blas AL, Armstrong DM: GABA(A) receptors in aging and Alzheimer's disease. J Neurochem 2007;103:12851292.

118 Lagostena L, Rosato-Siri M, D’Onofrio M, Brandi R, Arisi I, Capsoni S, Franzot J, Cattaneo A, Cherubini E: In the adult hippocampus, chronic nerve growth factor deprivation shifts GABAergic signaling from the hyperpolarizing to the depolarizing direction. J Neurosci 2010;30:885-893.

119 Choi DW: Excitotoxic cell death. J Neurobiol 1992;23:1261-1276.

- 120 Koh JY, Choi DW: Selective blockade of non-NMDA receptors does not block rapidly triggered glutamate-induced neuronal death. Brain Res 1991;548:318-321.

- 121 Berridge MJ, Bootman MD, Lipp P: Calcium - a life and death signal. Nature 1998; 395:645-648.

-122 Toescu EC, Verkhratsky A, Landfield PW: $\mathrm{Ca}^{2+}$ regulation and gene expression in normal brain aging. Trends Neurosci 2004;27: 614-620.

123 Emilsson L, Saetre P, Jazin E: Alzheimer's disease: mRNA expression profiles of multiple patients show alterations of genes involved with calcium signaling. Neurobiol Dis 2006;21:618-625.
124 Supnet C, Bezprozvanny I: The dysregulation of intracellular calcium in Alzheimer disease. Cell Calcium 2010;47:183-189.

125 Siman R, Noszek JC: Excitatory amino acids activate calpain I and induce structural protein breakdown in vivo. Neuron 1988; 1 : 279-287.

126 Barnett A, Brewer GJ: Autophagy in aging and Alzheimer's disease: pathologic or protective? J Alzheimers Dis 2011;25:385-394.

127 Hara T, Nakamura K, Matsui M, Yamamoto A, Nakahara Y, Suzuki-Migishima R, Yokoyama M, Mishima K, Saito I, Okano H, Mizushima N: Suppression of basal autophagy in neural cells causes neurodegenerative disease in mice. Nature 2006;441:885-889.

-128 Komatsu M, Waguri S, Chiba T, Murata S, Iwata J, Tanida I, Ueno T, Koike M, Uchiyama Y, Kominami E, Tanaka K: Loss of autophagy in the central nervous system causes neurodegeneration in mice. Nature 2006;441:880-884.

129 Hollenbeck PJ: Products of endocytosis and autophagy are retrieved from axons by regulated retrograde organelle transport. Cell Biol 1993;121:305-315.

$\checkmark 130$ Nixon RA, Wegiel J, Kumar A, Yu WH, Peterhoff C, Cataldo A, Cuervo AM: Extensive involvement of autophagy in Alzheimer disease: an immuno-electron microscopy study. J Neuropathol Exp Neurol 2005;64:113-122.

131 Nixon RA, Yang D-S: Autophagy failure in Alzheimer's disease - locating the primary defect. Neurobiol Dis 2011;43:38-45.

132 Terman A, Brunk UT: Oxidative stress, accumulation of biological 'garbage', and aging. Antioxid Redox Signal 2006;8:197204.

133 Moreira PI, Carvalho C, Zhu X, Smith MA, Perry G: Mitochondrial dysfunction is a trigger of Alzheimer's disease pathophysiology. Biochim Biophys Acta 2010;1802:210.

134 Glabe C: Intracellular mechanisms of amyloid accumulation and pathogenesis in Alzheimer's disease. J Mol Neurosci 2001; 17:137-145.

135 Vincent I, Rosado M, Davies P: Mitotic mechanisms in Alzheimer's disease? J Cell Biol 1996;132:413-425.

136 Vincent I, Jicha G, Rosado M, Dickson DW: Aberrant expression of mitotic cdc2/cyclin B1 kinase in degenerating neurons of Alzheimer's disease brain. J Neurosci 1997;17: 3588-3598.

137 Holzer M, Gartner U, Klinz FJ, Narz F, Heumann R, Arendt T: Activation of mitogen-activated protein kinase cascade and phosphorylation of cytoskeletal proteins after neurone-specific activation of p21ras. I. Mitogen-activated protein kinase cascade. Neuroscience 2001;105:1031-1040.

138 Zhu X, Lee HG, Raina AK, Perry G, Smith MA: The role of mitogen-activated protein kinase pathways in Alzheimer's disease. Neurosignals 2002;11:270-281.
139 Zhu X, Castellani RJ, Takeda A, Nunomura A, Atwood CS, Perry G, Smith MA: Differential activation of neuronal ERK, JNK/ SAPK and p38 in Alzheimer disease: the 'two hit' hypothesis. Mech Ageing Dev 2001;123:39-46.

140 Cotman CW, Anderson AJ: A potential role for apoptosis in neurodegeneration and Alzheimer's disease. Mol Neurobiol 1995; 10:19-45.

141 Pompl PN, Yemul S, Xiang Z, Ho L, Haroutunian V, Purohit D, Mohs R, Pasinetti GM: Caspase gene expression in the brain as a function of the clinical progression of Alzheimer disease. Arch Neurol 2003;60:369376.

142 Zheng H, Koo EH: The amyloid precursor protein: beyond amyloid. Mol Neurodegener 2006;1:5.

143 Yao M, Nguyen TV, Pike CJ: Beta-amyloidinduced neuronal apoptosis involves c-Jun $\mathrm{N}$-terminal kinase-dependent downregulation of Bcl-w. J Neurosci 2005;25:11491158.

144 Biswas SC, Shi Y, Vonsattel JP, Leung CL, Troy CM, Greene LA: Bim is elevated in Alzheimer's disease neurons and is required for beta-amyloid-induced neuronal apoptosis. J Neurosci 2007;27:893-900.

145 Tanzi RE, Bertram L: Twenty years of the Alzheimer's disease amyloid hypothesis: a genetic perspective. Cell 2005;120:545555

146 Vassar R, Kovacs DM, Yan R, Wong PC: The beta-secretase enzyme BACE in health and Alzheimer's disease: regulation, cell biology, function, and therapeutic potential. J Neurosci 2009;29:12787-12794.

147 Burdick D, Soreghan B, Kwon M, Kosmoski J, Knauer M, Henschen A, Yates J, Cotman C, Glabe C: Assembly and aggregation properties of synthetic Alzheimer's A4/ beta amyloid peptide analogs. J Biol Chem 1992;267:546-554.

148 Zhang YW, Thompson R, Zhang H, Xu H: APP processing in Alzheimer's disease. Mol Brain 2011;4:3.

149 Fukumoto H, Cheung BS, Hyman BT, Irizarry MC: Beta-secretase protein and activity are increased in the neocortex in Alzheimer disease. Arch Neurol 2002;59: 1381-1389.

150 Yang LB, Lindholm K, Yan R, Citron M, Xia W, Yang XL, Beach T, Sue L, Wong P, Price D, Li R, Shen Y: Elevated beta-secretase expression and enzymatic activity detected in sporadic Alzheimer disease. Nat Med 2003; 9:3-4.

151 Li R, Lindholm K, Yang LB, Yue X, Citron M, Yan R, Beach T, Sue L, Sabbagh M, Cai H, Wong P, Price D, Shen Y: Amyloid beta peptide load is correlated with increased beta-secretase activity in sporadic Alzheimer's disease patients. Proc Natl Acad Sci USA 2004;101:3632-3637. 
-152 Zhang X, Zhou K, Wang R, Cui J, Lipton SA, Liao FF, Xu H, Zhang YW: Hypoxia-inducible factor $1 \alpha$ (HIF-1 $\alpha)$-mediated hypoxia increases BACE1 expression and beta-amyloid generation. J Biol Chem 2007;282: 10873-10880.

153 Wen Y, Onyewuchi O, Yang S, Liu R, Simpkins JW: Increased beta-secretase activity and expression in rats following transient cerebral ischemia. Brain Res 2004;1009: $1-8$.

-154 Blasko I, Beer R, Bigl M, Apelt J, Franz G, Rudzki D, Ransmayr G, Kampfl A, Schliebs $\mathrm{R}$ : Experimental traumatic brain injury in rats stimulates the expression, production and activity of Alzheimer's disease betasecretase (BACE-1). J Neural Transm 2004; 111:523-536.

-155 Velliquette RA, O’Connor T, Vassar R: Energy inhibition elevates beta-secretase levels and activity and is potentially amyloidogenic in APP transgenic mice: possible early events in Alzheimer's disease pathogenesis. J Neurosci 2005;25:10874-10883.

>156 Nalivaeva NN, Fisk LR, Belyaev ND, Turner AJ: Amyloid-degrading enzymes as therapeutic targets in Alzheimer's disease. Curr Alzheimer Res 2008;5:212-224.

-157 Yasojima K, McGeer EG, McGeer PL: Relationship between beta amyloid peptide generating molecules and neprilysin in $\mathrm{Alz}$ heimer disease and normal brain. Brain Res 2001;919:115-121.

-158 Deane R, Du Yan S, Submamaryan RK, LaRue B, Jovanovic S, Hogg E, Welch D, Manness L, Lin C, Yu J, Zhu H, Ghiso J, Frangione B, Stern A, Schmidt AM, Armstrong DL, Arnold B, Liliensiek B, Nawroth P, Hofman F, Kindy M, Stern D, Zlokovic B: RAGE mediates amyloid-beta peptide transport across the blood-brain barrier and accumulation in brain. Nat Med 2003; 9:907-913

-159 Shibata M, Yamada S, Kumar SR, Calero M, Bading J, Frangione B, Holtzman DM, Miller CA, Strickland DK, Ghiso J, Zlokovic BV: Clearance of Alzheimer's amyloidss(1-40) peptide from brain by LDL receptor-related protein-1 at the blood-brain barrier. J Clin Invest 2000;106:1489-1499.

-160 Silverberg GD, Miller MC, Messier AA, Majmudar S, Machan JT, Donahue JE, Stopa EG, Johanson CE: Amyloid deposition and influx transporter expression at the blood-brain barrier increase in normal aging. J Neuropathol Exp Neurol 2010;69:98108.

-161 Bell RD, Zlokovic BV: Neurovascular mechanisms and blood-brain barrier disorder in Alzheimer's disease. Acta Neuropathol 2009; 118:103-113.

162 Braak H, Braak E: Staging of Alzheimer-related cortical destruction. Int Psychogeriatr 1997;9(suppl 1):257-261, discussion 269272.
163 Delacourte A, David JP, Sergeant N, Buee L, Wattez A, Vermersch P, Ghozali F, FalletBianco C, Pasquier F, Lebert F, Petit H, Di Menza C: The biochemical pathway of neurofibrillary degeneration in aging and $\mathrm{Alz}$ heimer's disease. Neurology 1999;52:11581165.

164 Thompson PM, Hayashi KM, de Zubicaray G, Janke AL, Rose SE, Semple J, Herman D, Hong MS, Dittmer SS, Doddrell DM, Toga AW: Dynamics of gray matter loss in Alzheimer's disease. J Neurosci 2003;23:9941005.

165 Hanks SD, Flood DG: Region-specific stability of dendritic extent in normal human aging and regression in Alzheimer's disease. I. CA1 of hippocampus. Brain Res 1991;540:63-82.

166 Gomez-Isla T, Hollister R, West H, Mui S, Growdon JH, Petersen RC, Parisi JE, Hyman BT: Neuronal loss correlates with but exceeds neurofibrillary tangles in Alzheimer's disease. Ann Neurol 1997;41:17-24.

167 Buell SJ, Coleman PD: Dendritic growth in the aged human brain and failure of growth in senile dementia. Science 1979;206:854856.

168 Bliss TV, Collingridge GL: A synaptic model of memory: long-term potentiation in the hippocampus. Nature 1993;361:31-39.

169 Neve RL, Finch EA, Bird ED, Benowitz LI: Growth-associated protein GAP-43 is expressed selectively in associative regions of the adult human brain. Proc Natl Acad Sci USA 1988;85:3638-3642.

170 Okuno H, Tokuyama W, Li YX, Hashimoto T, Miyashita Y: Quantitative evaluation of neurotrophin and trk mRNA expression in visual and limbic areas along the occipitotemporo-hippocampal pathway in adult macaque monkeys. J Comp Neurol 1999; 408:378-398

-171 Arendt T, Bruckner MK, Gertz HJ, Marcova L: Cortical distribution of neurofibrillary tangles in Alzheimer's disease matches the pattern of neurons that retain their capacity of plastic remodelling in the adult brain. Neuroscience 1998;83:991-1002.

-172 Masliah E, Mallory M, Veinbergs I, Miller A, Samuel W: Alterations in apolipoprotein E expression during aging and neurodegeneration. Prog Neurobiol 1996;50:493-503.

173 Stone DJ, Rozovsky I, Morgan TE, Anderson CP, Lopez LM, Shick J, Finch CE: Effects of age on gene expression during estrogen-induced synaptic sprouting in the female rat. Exp Neurol 2000;165:46-57.

174 Busciglio J, Ferreira A, Steward O, Caceres A: An immunocytochemical and biochemical study of the microtubule-associated protein tau during post-lesion afferent reorganization in the hippocampus of adult rats. Brain Res 1987;419:244-252.
175 Calkins MJ, Reddy PH: Amyloid beta impairs mitochondrial anterograde transport and degenerates synapses in Alzheimer's disease neurons. Biochim Biophys Acta 2011;1812:507-513.

176 Mesulam MM: Neuroplasticity failure in Alzheimer's disease: bridging the gap between plaques and tangles. Neuron 1999; 24:521-529.

177 Katzman R, Aronson M, Fuld P, Kawas C, Brown T, Morgenstern H, Frishman W, Gidez L, Eder H, Ooi WL: Development of dementing illnesses in an 80-year-old volunteer cohort. Ann Neurol 1989;25:317-324.

178 Aizenstein HJ, Nebes RD, Saxton JA, Price JC, Mathis CA, Tsopelas ND, Ziolko SK, James JA, Snitz BE, Houck PR, Bi W, Cohen AD, Lopresti BJ, DeKosky ST, Halligan EM, Klunk WE: Frequent amyloid deposition without significant cognitive impairment among the elderly. Arch Neurol 2008;65: 1509-1517.

179 Stern Y: What is cognitive reserve? Theory and research application of the reserve concept. J Int Neuropsychol Soc 2002;8:448460.

180 Stern Y: Cognitive reserve and Alzheimer disease. Alzheimer Dis Assoc Disord 2006; 20:112-117.

181 Zohar O, Cavallaro S, D’Agata V, Alkon DL: Quantification and distribution of betasecretase alternative splice variants in the rat and human brain. Mol Brain Res 2003; 115:63-68.

182 Aluise CD, Robinson RA, Beckett TL, Murphy MP, Cai J, Pierce WM, Markesbery WR, Butterfield DA: Preclinical Alzheimer disease: brain oxidative stress, $A \beta$ peptide and proteomics. Neurobiol Dis 2010;39:221-228.

183 Iacono D, O'Brien R, Resnick SM, Zonderman AB, Pletnikova O, Rudow G, An Y, West MJ, Crain B, Troncoso JC: Neuronal hypertrophy in asymptomatic Alzheimer disease. J Neuropathol Exp Neurol 2008;67: 578-589.

184 Jagust WJ, Landau SM, Shaw LM, Trojanowski JQ, Koeppe RA, Reiman EM, Foster NL, Petersen RC, Weiner MW, Price JC, Mathis CA: Relationships between biomarkers in aging and dementia. Neurology 2009;73:1193-1199.

185 Aluise CD, Robinson RA, Cai J, Pierce WM, Markesbery WR, Butterfield DA: Redox proteomics analysis of brains from subjects with amnestic mild cognitive impairment compared to brains from subjects with preclinical Alzheimer's disease: insights into memory loss in MCI. J Alzheimers Dis 2011;23:257-269.

186 Markesbery WR: Neuropathologic alterations in mild cognitive impairment: a review. J Alzheimers Dis 2010;19:221-228.

187 Scheff SW, Price DA, Schmitt FA, DeKosky ST, Mufson EJ: Synaptic alterations in CA1 in mild Alzheimer disease and mild cognitive impairment. Neurology 2007;68:15011508. 